\title{
ANALISIS SUMBER DAN PENGGUNAAN MODAL KERJA PADA KOPERASI PEGAWAI NEGERI SEJAHTERA BUSUNGBIU TAHUN 2016
}

\author{
Luh Diana Puspitayani \\ Jurusan Pendidikan Ekonomi, Fakultas Ekonomi \\ Universitas Pendidikan Ganesha Singaraja, \\ Indonesia
}

e-mail: anadianapuspita100@gmail.com

\begin{abstract}
Abstrak
Penelitian ini bertujuan untuk mendeskripsikan sumber dan penggunaan modal kerja pada koperasi Pegawai Negeri Sejahtera Busungbiu tahun 2016. Penelitian ini merupakan penelitian deskriptif kuantitatif. Subjek dalam penelitian ini adalah koperasi Pegawai Negeri Sejahtera Busungbiu, sedangkan objek dalam penelitian ini adalah sumber dan penggunaan modal kerja koperasi Pegawai Negeri Sejahtera Busungbiu periode 2014-2016. Sumber data yang digunakan adalah data sekunder. Data dikumpulkan dengan metode dokumentasi. Analisis data yang digunakan adalah analisis deskriptif. Hasil penelitian ini menunjukkan bahwa sumber modal kerja pada periode 2015-2016 berasal dari bertambahnya kewajiban jangka panjang dan bertambahnya ekuitas. Penggunaan modal kerja pada periode 2015-2016 digunakan untuk pengeluaran gaji, upah, biaya opersional, pembelian bahan baku atau bahan dagangan, pembentukan dana, pembelian aktiva tetap, dan pembayaran hutang jangka panjang.
\end{abstract}

Kata Kunci: Penggunaan Modal Kerja, Sumber Modal

\begin{abstract}
This study aims to describe the source and use of working capital in the cooperative civil servants Sejahtera Busungbiu 2016. This research is a quantitative descriptive research. Subjects in this study is cooperative civil servants Sejahtera Busungbiu, while the object in this study is the source and use of working capital of the cooperative civil servants Sejahtera Busungbiu period 2014-2016. The data source used is secondary data. Data were collected by documentation method. Data analysis used is descriptive analysis. The results of this study indicate that the source of working capital in the period 2015-2016 comes from the increase in long-term liabilities and increase in equity. The use of working capital in the period 2015-2016 is used for salary expenses, wages, operational costs, purchase of raw materials or merchandise, formation of funds, purchase of fixed assets, and repayment of long-term debt.
\end{abstract}

Keywords: Use of Working Capital, Source of Capital

\section{PENDAHULUAN}

Banyaknya jenis badan usaha yang ada, mulai dari Badan Usaha Milik Negara (BUMN), Badan Usaha Miliki Swasta (BUMS) hingga koperasi, diharapkan dapat saling mendukung guna menciptakan kesejahteraan masyarakat. Menurut Undang-Undang Republik Indonesia No. 25 Tahun 1992 tentang perkoperasian menjelaskan bahwa koperasi adalah badan usaha yang beranggotakan orang-seorang atau badan hukum koperasi dengan melandaskan kegiatannya berdasarkan prinsip koperasi sekaligus sebagai gerakan ekonomi rakyat yang berdasar atas asas kekeluargaan. Dalam kegiatannya, koperasi berlandaskan asas kekeluargaan dan koperasi bertujuan untuk memajukan kesejahteraan anggota pada khususnya dan masyarakat pada umumnya serta ikut membangun tatanan perekonomian nasional dalam rangka mewujudkan masyarakat yang maju, adil, dan makmur berlandaskan pancasila dan 
Undang-Undang Dasar 1945. Menurut Subandi (2013), koperasi berasal dari bahasa Inggris co-operation yang berarti usaha bersama. Dengan kata lain berarti segala pekerjaan yang dilakukan secara bersama-sama sebenarnya dapat disebut sebagai koperasi, menurut Muljono (2012), koperasi adalah badan usaha yang beranggotaan orang-seorang atau badan hukum, sedangkan menurut Sitio (2001), menyatakan bahwa koperasi adalah badan usaha bersama untuk memperbaiki nasib kehidupan ekonomi berdasarkan tolong-menolong.

Seperi badan usaha lainnya, koperasi juga memiliki tujuan. Tujuan mendirikan sebuah koperasi adalah untuk membangun sebuah organisasi usaha dalam memenuhi kepentingan bersama dari para pendiri dan anggotanya di bidang ekonomi, (Pachta, 2005), sedangkan menurut Sudarwanto (2013) tujuan uama koperasi adalah meningkatkan kesejahteraan anggotanya, memajukan kesejahteraan masyarakat, turut membangun tatanan perekonomian nasional. Dalam rangka mencapai tujuan untuk memajukan kesejahteraan anggota pada khususnya dan masyarakat pada umumnya, koperasi tentu saja harus mengelola modal yang ada sebaik mungkin, supaya dapat memberikan hasil usaha yang kemudian dapat dimanfaatkan kembali untuk kesejahteraan anggota. Agar dalam pelaksanaan kegiatan perusahaan berhasil mencapai tujuan, diperlukan sejumlah modal kerja yang cukup.

Menurut Undang-Undang Republik Indonesia No. 25, pasal 41 tentang modal koperasi, modal koperasi terdiri atas modal sendiri dan modal pinjaman. Modal sendiri meliputi simpanan pokok, simpanan wajib, dana cadangan, dan hibah. Modal pinjaman koperasi berasal dari anggota, koperasi lainnya dan atau anggotanya, bank dan lembaga keuangan lainnya, penerbitan obligasi dan surat hutang lainnya dan sumber lain yang sah. Menurut Riyanto (2001) modal kerja menurut jenisnya dapat dibedakan menjadi dua golongan yaitu modal kerja permanen dan modal kerja variabel.

Menurut Jumingan (2008), Modal kerja adalah kelebihan aktiva lancar terhadap hutang jangka pendek. Kelebihan ini disebut dengan modal kerja bersih (net working capital). Kelebihan ini merupakan jumlah aktiva lancar yang berasal dari utang jangka panjang dan modal sendiri. Definisi ini bersifat kualitatif karena menunjukkan kemungkinan tersedianya aktiva lancar yang lebih besar daripada utang jangka pendek dan menunjukkan tingkat keamanan bagi kreditur jangka pendek serta menjamin kelangsungan diusaha mendatang, sedangkan menurut Amidipradja (2005) menjelaskan bahwa modal kerja koperasi adalah kelebihan jumlah harta terhadap jumlah utang dari koperasi, atau dengan kata lain selisih positif antara harta dan utang. Modal kerja merupakan faktor yang sangat penting bagi perkembangan dan kemajuan koperasi sekaligus berfungsi sebagai penjaga kepercayaan masyarakat. Setiap penciptaan aktiva, disamping berpotensi menghasilkan keuntungan juga menimbulkan resiko. Oleh karena itu modal juga harus dapat digunakan untuk menjaga kemungkinan terjadinya resiko kerugian atas investasi pada aktiva, terutama yang berasal dari dana-dana pihak ketiga atau masyarakat.

Adanya modal kerja yang cukup sangat penting bagi suatu koperasi karena dengan modal kerja yang cukup itu memungkinkan bagi perusahaan untuk beroperasi dengan seekonomis mungkin dan perusahaan tidak mengalami kesulitan atau menghadapi bahaya-bahaya yang mungkin timbul karena kekacauan keuangan (Subandi, 2013), akan tetapi adanya modal kerja yang berlebihan menunjukkan adanya dana yang tidak produktif, dan dalam hal ini akan menimbulkan kerugian bagi perusahaan karena adanya kesempatan untuk memperoleh keuntungan tapi disia-siakan, sebaliknya adanya ketidak cukupan dalam modal kerja merupakan sebab 
utama kegagalan suatu perusahaan. Menurut Sartono (2010) modal kerja diperlukan perusahaan untuk membiayai kegiatan operasional perusahaan, sumber modal kerja menurut Munawir (2004) adalah adanya penurunan dalam non current assets karena penjualan maupun proses depresiasi, kenaikan dalam non current liabilities atau hutang jangka panjang, dan Adanya kenaikan dalam sektor modal dari setoran pemilik maupun dari hasil operasi.

Setelah memperoleh modal kerja yang diinginkan, kemudian koperasi menggunakan modal kerja tersebut untuk mencapai ujuannya. Hubungan antara sumber dan penggunaan modal kerja sangat erat, artinya penggunaan modal kerja dipilih dari sumber modal tertentu atau sebaliknya. Penggunaan modal kerja akan dapat mempengaruhi jumlah modal kerja itu sendiri. Menurut Kasmir (2014), seorang manajer dituntut untuk menggunakan modal kerja secara tepat, sesuai dengan saran yang ingin dicapai perusahaan. Penggunaan dana untuk modal kerja dapat diperoleh dari kenaikan aktiva dan menurunnya pasiva. Penggunaan modal kerja menurut Munawir (2004) adalah adanya kenaikan sektor non current asset, penurunan dalam sektor non current liabilities atau hutang jangka panjang, dan adanya kerugian dalam sektor modal dan operasi perusahaan, sedangkan penggunaan modal kerja menurut Kasmir (2014) penggunaan modal kerja bisa dilakukan untuk pengeluaran untuk gaji, upah, dan biaya opersional, pengeluaran untuk membeli bahan baku atau bahan dagagan, menutupi kerugian akibat penjualan surat berharga, pembentukan dana, pembelian aktiva tetap, pembayaran hutang jangka panjang, dan penggunaan lainnya.

Koperasi Pegawai Negeri (KPN) Sejahtera merupakan koperasi yang beranggotakan guru-guru Sekolah Dasar se-kecamatan Busungbiu, Pegawai Kantor UPP dan Pegawai dari Koperasi Pegawai Negeri Sejahtera itu sendiri. Bidang usaha KPN Sejahtera diantaranya usaha simpan pinjam, usaha pertokoan, dan usaha kerja sama dengan pihak ketiga atau mitra kerja, sehingga membutuhkan manajemen yang baik yang dapat mengelola keuangan. Dalam menjalankan kegiatan usahanya kas sebagai modal kerja diperlukan untuk membiayai operasional sehari-hari. Penerimaan dan pengeluaran kas dalam koperasi akan berlangsung secara terusmenerus selama hidup koperasi.

Selama kurun waktu dari tahun 2014-2015 sumber modal kerja Koperasi Pegawai Negri (KPN) Sejahtera mengalami penurunan pada tahun 2015 jika dibandingkan dengan tahun 2014. Tahun 2014 jumlah modal kerja koperasi sebesar Rp.6.244.473.756,25 yang didapat dari aktiva lancar sebesar Rp.8.626.885.474,34 yang dikurangi dengan utang jangka pendek sebesar Rp.2.382.411.718,09, sedangkan tahun 2015 jumlah modal kerja koperasi sebesar Rp.5.844.994.688,94 yang didapat dari aktiva lancar sebesar Rp.7.920.068.707,49 yang dikurangi dengan utang jangka pendek sebesar Rp.2.075.074.018,55, sehingga dapat dikatakan modal kerja koperasi pada tahun 2015 mengalami penurunan modal kerja sebesar Rp. 399. 479.067,31 atau 6,39\%. Modal kerja dari tahun 2014 dan 2015 mengalami penurunan karena banyaknya biayabiaya yang dikeluarkan untuk operasional koperasi dan lain-lain yang tidak diimbangi dengan kenaikan aktiva lancar.

Berdasarkan uraian di atas, maka penulis memberi judul penelitian ini analisis sumber dan penggunaan modal kerja pada koperasi pegawai negeri sejahtera busungbiu tahun 2016. Tujuan yang ingin dicapai dalam penelitian ini adalah mengetahui sumber dan penggunaan modal kerja pada Koperasi Pegawai Negeri (KPN) Sejahtera Busungbiu tahun 2016.

\section{METODE}

Rancangan penelitian yang digunakan adalah penelitian deskriptif 
pada Koperasi Pegawai Negeri (KPN) Sejahtera Busungbiu yaitu untuk mengetahui apa saja sumber modal kerja dan bagaimana penggunaannya. Data yang dicari adalah laporan keuangan berupa neraca koperasi pada tahun 2014, 2015 dan 2016. Data tersebut kemudian dianalisis dengan menggunakan analisis perbandingan.

Dengan membandingkan pos-pos pada neraca pada tahun 2014-2016 yang berhubungan dengan sumber dan penggunaan modal bertujuan untuk mendapatkan informasi perkembangan keadaan keuangan koperasi. Hasil analisis laporan sumber dan penggunan modal kerja diharapkan dapat membantu pengelola koperasi mengetahui apa saja sumber modal koperasi dan bagaimana modal loperasi tersebut digunakan selama periode tertentu, sehingga dari hasil penelitian terebut dapat digunakan pengelola koperasi untuk mengambil keputusan tentang pemodalan.

Lokasi penelitian adalah di Koperasi Pegawai Negeri (KPN) Sejahtera yang beralamat di Jalan Menaka Giri, Desa Busungbiu, Kecamatan Busungbiu, Kabupaten Buleleng, Provinsi Bali. Subjek dalam penelitian ini adalah Koperasi Pegawai Negeri Sejahtera Busungbiu, laporan yang digunakan merupakan laporan keuangan berupa neraca periode 20142016. Objek kajian penelitian ini adalah sumber dan penggunaan modal kerja pada Koperasi Pegawai Negeri (KPN) Sejahtera Busungbiu. Berdasarkan jenisnya, data yang digunakan dalam penelitian ini adalah data kuantitatif. Data kuantitatif yang digunakan berupa Neraca Koperasi Pegawai Negeri (KPN) Sejahtera. Berdasarkan sumbernya, data yang digunakan dalam penelitian ini adalah data sekunder. Data sekunder yang digunakan meliputi laporan keuangan berupa Neraca Koperasi Pegawai Negeri (KPN) Sejahtera.

Metode pengumpulan data yang digunakan dalam penelitian ini adalah dokumentasi. Dokumen yang digunakan berupa laporan keuangan koperasi yaitu
Neraca. Analisis data yang digunakan dalam penelitian ini adalah deskriptif kuantitatif. Penelitian ini disajikan dalam bentuk deskriptif yang membahas tentang apa saja sumber modal koperasi dan bagaimana penggunaan modal kerja koperasi.

Tahap-tahap analisis data dapat dilakukan setelah memperoleh data dengan metode dokomentasi berupa neraca koperasi pada tahun 2014-2016, kemudian data-data tersebut diolah dan dianalisis untuk mencapai tujuan akhir penelitian. Dalam hal ini peneliti melakukan analisis perbandingan yaitu membandingkan pos-pos yang ada pada neraca yang berhubungan dengan sumber dan penggunaan modal kerja.

\section{HASIL DAN PEMBAHASAN Hasil}

Berdasarkan hasil analisis sumber modal kerja yang telah dilakukan pada Koperasi Pegawai Negeri Sejahtera pada periode tahun 2014-2016, total sumber modal kerja Koperasi Pegawai Negeri Sejahtera pada periode tahun 2014-2015 adalah Rp.183.784.798,12, dapat diuraikan unsur-unsur non current yang memperbesar modal kerja (sumber modal kerja). Sumber-sumber modal kerja pada Koperasi Pegawai Negeri Sejahtera Busungbiu periode tahun 2014-2015 berasal dari (1) berkurangnya aktiva lain-lain ( piutang ragu-ragu), berkurangnya aktiva lainlain berasal dari piutang ragu-ragu yang merupakan sumber modal kerja bagi Koperasi Pegawai Negeri Sejahtera Busungbiu. Berkurangnya piutang raguragu dari periode tahun 2014-2015 yaitu sebesar Rp.4.707.700,00, karena pada tahun 2014 piutang ragu-ragu Koperasi Pegawai Negeri Sejahtera Busungbiu adalah Rp.14.279.600,00 sedangkan piutang ragu-ragu Koperasi Pegawai Negeri Sejahtera Busungbiu pada tahun 2015 sebesar Rp.9.571.900,00. Berkurangnya aktiva lain-lain yaitu berkurangnya piutang ragu-ragu karena terjadinya pelunasan piutang ragu-ragu kepada koperasi sebesar Rp.4.707.700,00, (2) bertambahnya kewajiban jangka panjang (hutang PKP- 
$\mathrm{RI}$ ), bertambahnya kewajiban jangka panjang yang berasal dari hutang PKP$\mathrm{RI}$ yang merupakan sumber modal kerja bagi Koperasi Pegawai Negeri Sejahtera Busungbiu. Bertambahnya hutang PKP-RI dari periode tahun 20142015 yaitu sebesar Rp.63.500.000,00, karena pada tahun 2014 hutang PKP-RI Koperasi Pegawai Negeri Sejahtera Busungbiu adalah Rp.193.000.000,00 sedangkan hutang PKP-RI Koperasi Pegawai Negeri Sejahtera Busungbiu pada tahun 2015 sebesar Rp.256.500.000,00. Bertambahnya kewajiban jangka panjang yaitu hutang PKP-RI karena koperasi melakukan peminjaman kepada PKP-RI sebesar Rp.63.500.000,00, (3) bertambahnya equitas (simpanan wajib dan cadangan koperasi), bertambahnya ekuitas yang berasal dari simpanan wajib yang merupakan sejumlah simpanan tertentu yang wajib dibayar oleh anggoa kepada koperasi dalam waktu dan kesempatan tertentu dan simpanan wajib ini tidak dapat diambil kembali selama masih menjadi anggota sehingga simpanan wajib merupakan sumber modal kerja bagi Koperasi Pegawai Negeri Sejahtera Busungbiu Bertambahnya simpanan wajib dari periode tahun 2014-2015 yaitu sebesar Rp.85.668.099,82, karena pada tahun 2014 jumlah simpanan wajib anggota Koperasi adalah Rp.1.833.020.728,97, sedangkan simpanan wajib anggota Koperasi Pegawai Negeri Sejahtera Busungbiu pada tahun 2015 sebesar Rp.1.918.688.828,79. Bertambahnya equitas juga berasal dari bertambahnya cadangan yang merupakan sejumlah uang yang diperoleh dari penyisihan Sisa Hasil Usaha (SHU), yang dimagsudkan untuk memupuk modal sendiri dan untuk menutupi kerugian koperasi bila diperlukan sehingga dana cadangan merupakan sumber modal kerja bagi Koperasi Pegawai Negeri Sejahtera Busungbiu . Bertambahnya cadangan koperasi dari tahun 20142015 yaitu sebesar Rp.29.908.998,30, karena pada tahun 2014 jumlah cadangan Koperasi Pegawai Negeri Sejahtera Busungbiu adalah
Rp.481.005.377,71, sedangkan cadangan Koperasi Pegawai Negeri Sejahtera Busungbiu pada tahun 2015 sebesar Rp.510.914.376,01. Bertambahnya ekuitas yaitu bertambahnya simpanan wajib karena bertambahnya jumlah simpanan wajib yang ditetapkan koperasi dan bertambahnya jumlah anggota koperasi, sedangkan bertambahnya cadangan koperasi diperoleh dari Sisa Hasil Usaha (SHU).

Hasil analisis sumber modal kerja yang telah dilakukan pada Koperasi Pegawai Negeri Sejahtera pada periode tahun 2015-2016, total sumber modal kerja pada periode tahun 2015-2016 adalah Rp. Rp.252.555.875,42, dapat diuraikan unsur-unsur non current yang memperbesar modal kerja (sumber modal kerja). Sumber-sumber modal kerja pada Koperasi Pegawai Negeri Sejahtera Busungbiu periode tahun 2015-2016 berasal dari (1) bertambahnya kewajiban jangka panjang (hutang PKP-RI), bertambahnya kewajiban jangka panjang yang berasal dari hutang PKP$\mathrm{RI}$ yang merupakan sumber modal kerja bagi Koperasi Pegawai Negeri Sejahtera Busungbiu. Bertambahnya hutang PKP-RI dari tahun 2015-2016 yaitu sebesar Rp.80.800.000,00, karena pada tahun 2015 hutang PKP-RI Koperasi Pegawai Negeri Sejahtera Busungbiu adalah Rp.256.500.000,00, sedangkan hutang PKP-RI Koperasi Pegawai Negeri Sejahtera Busungbiu pada tahun 2016 sebesar Rp.337.300.000,00. Bertambahnya kewajiban jangka panjang yaitu bertabahnya hutang PKP-RI karena koperasi melakukan peminjaman kepada PKP-RI sebesar Rp.80.800.000,00, (2) bertambahnya equitas (simpanan wajib, cadangan resiko piutang dan cadangan), bertambahnya ekuitas yang berasal dari simpanan wajib, cadangan resiko piutang dan cadangan yang merupakan sumber modal kerja bagi Koperasi Pegawai Negeri Sejahtera Busungbiu. Bertambahnya simpanan wajib dari tahun 2015-2016 yaitu sebesar 
Rp.130.219.008,00, karena pada tahun 2015 jumlah simpanan wajib anggota Koperasi Pegawai Negeri Sejahtera Busungbiu adalah Rp1.918.688.828,79, sedangkan simpanan wajib anggota Koperasi Pegawai Negeri Sejahtera Busungbiu pada tahun 2016 sebesar Rp.2.048.907.836,79. Bertambahnya equitas juga berasal dari bertambahnya cadangan resiko piutang. Bertambahnya cadangan resiko piutang koperasi dari tahun 2015-2016 yaitu sebesar Rp.27.097.500,00, karena pada tahun 2015 jumlah cadangan resiko piutang Koperasi Pegawai Negeri Sejahtera Busungbiu adalah Rp.591.584.924,53, sedangkan cadangan resiko piutang Koperasi Pegawai Negeri Sejahtera Busungbiu pada tahun 2016 sebesar Rp.618.682.424,53. Selain simpanan wajib dan cadangan resiko piutang, bertambahnya equitas juga berasal dari bertambahnya dana cadangan. Bertambahnya cadangan koperasi dari tahun 2015-2016 yaitu sebesar Rp.14.439.367,42, karena pada tahun 2015 jumlah cadangan resiko piutang Koperasi Pegawai Negeri Sejahtera Busungbiu adalah Rp.510.914.376,01, sedangkan cadangan resiko piutang Koperasi Pegawai Negeri Sejahtera Busungbiu pada tahun 2016 sebesar Rp.525.353.743,43. Bertambahnya equitas yaitu bertambahnya simpanan wajib karena bertambahnya jumlah simpanan wajib yang ditetapkan koperasi dan bertambahnya jumlah anggota koperasi, sedangkan bertambahnya cadangan resiko piutang dan cadangan koperasi diperoleh dari Sisa Hasil Usaha (SHU).

Berdasarkan hasil analisis penggunaan modal kerja yang telah dilakukan pada Koperasi Pegawai Negeri Sejahtera pada periode tahun 2014-2016, total penggunaan modal kerja pada tahun 2014-2015 adalah Rp.583.263.865,43, dapat diuraikan unsur-unsur non current yang memperkecil modal kerja (penggunaan modal kerja). Penggunaan modal kerja pada Koperasi Pegawai Negeri Sejahtera Busungbiu periode tahun
2014-2015 yaitu (1) bertambahnya aset tidak lancar (simpanan PKP RI), bertambahnya aset tidak lancar yang berasal dari simpanan PKP RI yang merupakan penggunaan modal kerja bagi Koperasi Pegawai Negeri Sejahtera Busungbiu. Bertambahnya simpanan PKP RI dari tahun 2014-2015 yaitu sebesar Rp.11.400.000,00, karena pada tahun 2014 jumlah simpanan PKP RI adalah Rp.90.160.674,00, sedangkan jumlah simpanan PKP RI pada tahun 2015 sebesar Rp.101.560.674,00. Bertambahnya aset tidak lancar karena bertambahnya simpanan koperasi Pegawai Negeri Seahtera pada PKP RI sebesar Rp.11.400.000,00, (2) bertambahnya aset tetap (akumulasi penyusutan bangunan) dan akumulasi penyusutan peralatan), bertambahnya aset tetap yang berasal dari akumulasi penyusutan bangunan dan akumulasi penyusutan peralatan yang merupakan penggunaan modal kerja bagi Koperasi Pegawai Negeri Sejahtera Busungbiu. Bertambahnya akumulasi penyusutan. bangunan dari tahun 2014-2015 yaitu sebesar Rp.9.989.461,25, karena pada tahun 2014 jumlah akumulasi penyusutan bangunan adalah Rp.59.936.767,50, sedangkan jumlah akumulasi penyusutan bangunan pada tahun 2015 sebesar Rp.69.926.228,75. Selain bertambahnya akumulasi penyusutan. bangunan, bertambahnya aset tetap juga berasal dari akumulasi penyusutan peralatan, dari tahun 20142015 yaitu sebesar Rp.3.320.000,00 karena pada tahun 2014 jumlah akumulasi penyusutan peralatan adalah Rp.40.360.650,00, sedangkan jumlah akumulasi penyusutan peralatan pada tahun 2015 sebesar Rp.43.680.650,00. Bertambahnya aset tetap karena terjadinya penyusutan pada bangunan sebesar Rp.9.989.461,25, dan penyusutan peralatan Rp.3.320.000,00, (3) berkurangnya ekuitas (simpanan pokok, simpanan wajib khusus, cadangan resiko piutang, dan Sisa Hasil Usaha), berkurangnya ekuitas yang berasal dari simpanan pokok, simpanan wajib khusus, cadangan resiko piutang, 
dan Sisa Hasil Usaha (SHU) yang merupakan penggunaan modal kerja bagi Koperasi Pegawai Negeri Sejahtera Busungbiu. Berkurangnya simpanan pokok dari tahun 2014-2015 yaitu sebesar Rp.161.000,00, karena pada tahun 2014 jumlah simpanan pokok adalah Rp.2.982.000,00, sedangkan jumlah simpanan pokok pada tahun 2015 sebesar Rp.2.821.000,00. Berkurangnya simpanan wajib khusus dari tahun 2014 -2015 yaitu sebesar Rp.347.222.627,91, karena pada tahun 2014 jumlah simpanan wajib khusus adalah Rp.3.241.617.196,60, sedangkan jumlah simpanan wajib khusus pada tahun 2015 sebesar Rp.2.894.394.568,69. Berkurangnya cadangan resiko piutang dari tahun 2014-2015 yaitu sebesar Rp.83.093.389,94, karena pada tahun 2014 jumlah cadangan resiko piutang adalah Rp.674.678.314,47, sedangkan jumlah cadangan resiko piutang pada tahun 2015 sebesar Rp.591.584.924,53. Berkurangnya Sisa Hasil Usaha (SHU) dari tahun 20142015 yaitu sebesar Rp.154.696.308,83, karena pada tahun 2014 jumlah SHU adalah Rp.299.089.983,00, sedangkan jumlah SHU pada tahun 2015 sebesar Rp.144.393.674,17. Berkurangnya equitas yaitu berkurangnya simpanan pokok, simpanan wajib khusus, cadangan resiko piutang, dan Sisa Hasil Usaha (SHU) karena diigunakan untuk biaya operasional koperasi.

Hasil analisis penggunaan modal kerja yang telah dilakukan pada Koperasi Pegawai Negeri Sejahtera pada periode tahun 2015-2016,total penggunaan modal kerja pada periode tahun 2015-2016 adalah Rp.186.226.795,14, dapat diuraikan unsure-unsur non current yang memperkecil modal kerja (penggunaan modal kerja). Penggunaan modal kerja pada Koperasi Pegawai Negeri Sejahtera Busungbiu periode tahun 2015-2016 yaitu (1) bertambahnya aset tidak lancar (simpanan PKP RI), bertambahnya aset tidak lancar yang berasal dari simpanan PKP RI yang merupakan penggunaan modal kerja bagi Koperasi Pegawai Negeri Sejahtera Busungbiu. Bertambahnya simpanan PKP RI dari tahun 2015-2016 yaitu sebesar Rp.13.547.419,23, karena pada tahun 2015 jumlah simpanan PKP RI adalah Rp.101.560.674,00, sedangkan jumlah simpanan PKP RI pada tahun 2016 sebesar Rp.115.108.093,23. Bertambahnya aset tidak lancar karena bertambahnya simpanan koperasi Pegawai Negeri Seahtera pada PKP RI sebesar Rp.13.547.419,23, (2) bertambahnya aset tetap (peralatan), bertambahnya aset tetap yang berasal dari peralatan yang merupakan penggunaan modal kerja bagi Koperasi Pegawai Negeri Sejahtera Busungbiu. Bertambahnya peralatan dari tahun 2015- 2016 yaitu sebesar Rp.1.749.000,00, karena pada tahun 2015 jumlah peralatan adalah Rp.58.808.550,00, sedangkan jumlah peralatan pada tahun 2016 sebesar Rp.60.557.550,00. Bertambahnya aset tetap yaitu bertambahnya peralatan karena terjadinya pembelian peralatan oleh koperasi sebesar sebesar Rp.1.749.000,00, (3) berkurangnya equitas (simpanan pokok, simpanan wajib khusus dan Sisa Hasil Usaha), berkurangnya ekuitas yang berasal dari simpanan pokok, simpanan wajib khusus dan Sisa Hasil Usaha (SHU) yang merupakan penggunaan modal kerja bagi Koperasi Pegawai Negeri Sejahtera Busungbiu. Berkurangnya simpanan pokok dari tahun 2015- 2016 yaitu sebesar Rp.120.000,00, karena pada tahun 2015 jumlah simpanan pokok adalah Rp.2.821.000,00, sedangkan jumlah simpanan pokok pada tahun 2016 sebesar Rp.2.701.000,00. Berkurangnya simpanan wajib khusus dari tahun 2015-2016 yaitu sebesar Rp.135.927.590,90, karena pada tahun 2015 jumlah simpanan wajib khusus adalah Rp.2.894.394.568,69, sedangkan jumlah simpanan wajib khusus pada tahun 2016 sebesar Rp.2.758.466.977,79. Berkurangnya Sisa Hasil Usaha (SHU) dari tahun 2015-2016 yaitu sebesar 
Rp.34.882.785,01, karena pada tahun 2015 jumlah Sisa Hasil Usaha (SHU) adalah Rp.144.393.674,17, sedangkan jumlah Sisa Hasil Usaha (SHU) pada tahun 2016 sebesar Rp.109.510.889,16. Berkurangnya equitas yaitu berkurangnya simpanan pokok, simpanan wajib khusus dan SHU karena digunakan untuk biaya operasional koperasi.

Hasil analisis sumber dan penggunaan modal kerja Koperasi Pegawai Negeri Sejahtera Busungbiu periode per 31 Desember 2014-2016 dapat dilihat bahwa sumber modal kerja Koperasi Pegawai Negeri Sejahtera Busungbiu periode tahun 2015-2016 adalah Rp.252.555.875,42, sedangkan sumber modal kerja Koperasi Pegawai Negeri Sejahtera Busungbiu periode tahun 2014-2015 adalah Rp.183.784.798,12, sehingga dapat dikatakan sumber modal kerja koperasi periode tahun 2015-2016 lebih besar dari pada sumber modal kerja koperasi periode tahun 2014-2015 yang mengalami peningkatan sebesar Rp.68.771.077,30 atau 37, 41\%. Sumber modal kerja pada Koperasi Pegawai Negeri Sejahtera Busungbiu periode tahun 2015-2016 berasal dari bertambahnya kewajiban jangka panjang yaitu bertambahnya hutang PKP-RI sebesar Rp.80.800.000,00, bertambahnya ekuitas atau modal sendiri yaitu bertambahnya simpanan wajib sebesar Rp.130.219.008,00, bertambahnya cadangan resiko piutang sebesar Rp.27.097.500,00 dan bertambahnya cadangan sebesar Rp.14.439.367,42. Bertambahnya modal kerja Temuan-temuan pada sumber modal kerja sejalan dengan pernyataan Munawir (2004) sumber modal kerja adalah adanya penurunan dalam non current assets karena penjualan maupun proses depresiasi, kenaikan dalam non current liabilities atau hutang jangka panjang, dan adanya kenaikan dalam sektor modal dari setoran pemilik maupun dari hasil operasi. Menurut Undang-Undang Republik Indonesia No. 25, pasal 41 tentang modal koperasi menyatakan
Modal koperasi terdiri atas modal sendiri dan modal pinjaman. Modal kerja Koperasi Pegawai Negeri Sejahtera Busungbiu sesuai dengan Undang-Undang Republik Indonesia No. 25, pasal 41 yaitu terdiri atas modal sendiri dan modal pinjaman. Sumber modal sendiri pada Koperasi Pegawai Negeri Sejahtera Busungbiu adalah simpanan wajib, dana cadangan resiko piutang dan cadangan, sedangkan modal pinjaman berasal dari PKP-RI. Bertambahnya modal kerja koperasi terjadi karena bertambahnya sumber modal koperasi sebesar Rp. 252.555.875,42 yang lebih besar dari penggunaan modal koperasi sebesar Rp. 186.226.795,14. Dengan adanya kenaikan modal kerja diharapkan nantinya Koperasi Pegawai Negeri Sejahtera Busungbiu mampu membiayai pengeluaran-pengeluaran atau operasi perusahaan sehari-hari, mampu beroperasi secara ekonomis atau efisien dan perusahaan tidak mengalami kesulitan keuangan.

Sumber modal kerja pada periode tahun 2015-2016 sebesar Rp.252.555.875,42 yang berasal dari hutang PKP-RI, simpanan wajib, cadangan resiko piutang dan cadangan tersebut kemudian digunakan sebesar Rp. 186.226.795,24 untuk 1) pengeluaran untuk gaji, upah, dan biaya opersional, yaitu pembayaran gaji karyawan sebesar Rp. 130.000.000,00, biaya pemeliharaan inventaris sebesar Rp.7.392.400,86, biaya administrasi sebesar Rp.6.000.000,00, pembayaran dana sosial sebesar Rp.3720.058,66, pembayaran dana pendidikan sebesar Rp.10.090.262,01, pembayaran dana pembangunan daerah sebesar Rp.167.529,33, 2) pengeluaran untuk membeli bahan baku atau bahan dagagan yaitu pembelian bahan baku untuk toko sebesar Rp.2.953.875,15, 3) pembentukan dana yaitu simpanan pada PKP-RI sebesar Rp.13.547.419,23, 4) pembelian aktiva tetap yaitu pembelian peralatan kantor sebesar Rp.1.749.000,00 5) pembayaran hutang jangka panjang yaitu pembayaran biaya bunga 
pinjaman PKP RI sebesar

Rp.10.606.250,00.

Penggunaan modal kerja

Koperasi Pegawai Negeri Sejahtera Busungbiu periode per 31 Desember 2015-2016 adalah Rp.186.226.795,14, sedangkan penggunaan modal kerja Koperasi Pegawai Negeri Sejahtera Busungbiu periode tahun 2014-2015 adalah Rp.583.263.865,43, sehingga dapat dikatakan penggunaan modal kerja koperasi periode tahun 2015-2016 lebih kecil dari pada penggunaan modal kerja koperasi periode tahun 2014-2015 yang mengalami penurunan sebesar Rp.397.037.070,29 atau 68,07\%. Terjadinya penurunan penggunaan modal kerja pada Koperasi Pegawai Negeri Sejahtera Busungbiu dikarenakan Koperasi Pegawai Negeri Sejahtera Busungbiu mampu menggunakan modal kerja secara tepat, sesuai dengan saran yang ingin dicapai koperasi dan tidak melebihi dari modal kerja yang ada.

Dari temuan-temuan pada penggunaan modal kerja ini sejalan dengan teori penggunaan modal kerja yang dikemukakan oleh Kasmir (2014) penggunaan modal kerja bisa dilakukan untuk pengeluaran untuk gaji, upah, dan biaya opersional, pengeluaran untuk membeli bahan baku atau bahan dagagan, menutupi kerugian akibat penjualan surat berharga, pembentukan dana, pembelian aktiva tetap, pembayaran hutang jangka panjang, dan penggunaan lainnya.

\section{SIMPULAN DAN SARAN Simpulan}

Berdasarkan hasil penelitian dan pembahasan, maka dapat diambil kesimpulan sebagai berikut sumber modal kerja pada Koperasi Pegawai Negeri Sejahtera Busungbiu periode tahun 2015-2016 berasal dari bertambahnya kewajiban jangka panjang yaitu bertambahnya hutang PKP-RI sebesar Rp.80.800.000,00, bertambahnya equitas atau modal yaitu bertambahnya simpanan wajib sebesar Rp.130.219.008,00, bertambahnya cadangan resiko piutang sebesar
Rp.27.097.500,00 dan bertambahnya cadangan sebesar Rp.14.439.367,42, penggunaan modal kerja pada Koperasi Pegawai Negeri Sejahtera Busungbiu periode tahun 2015-2016 untuk pengeluaran untuk gaji, upah, dan biaya opersional, yaitu pembayaran gaji karyawan sebesar Rp. 130.000.000,00, biaya pemeliharaan inventaris sebesar Rp.7.392.400,86, biaya administrasi sebesar Rp.6.000.000,00, pembayaran dana sosial sebesar Rp.3.720.058,66, pembayaran dana pendidikan sebesar Rp.10.090.262,01, pembayaran dana pembangunan daerah sebesar Rp.167.529,33, pengeluaran untuk membeli bahan baku atau bahan dagagan yaitu pembelian bahan baku untuk toko sebesar Rp.2.953.875,15, pembentukan dana yaitu simpanan pada PKP-RI sebesar Rp.13.547.419,23, pembelian aktiva tetap yaitu pembelian peralatan kantor sebesar Rp.1.749.000,00, pembayaran hutang jangka panjang yaitu pembayaran biaya bunga pinjaman PKP RI sebesar Rp.10.606.250,00.

\section{Saran}

Berdasarkan hasil kesimpulan di atas, maka dapat dikemukakan beberapa saran bagi Koperasi Pegawai Negeri (KPN) Sejahtera Busungbiu, diharapkan dari pihak koperasi untuk merencanakan penggunakan modal kerja dengan baik agar penggunaan modal kerja koperasi tidak melebihi dari modal kerja yang ada, sehingga koperasi memiliki modal yang cukup untuk menjalankan koperasinya, jika koperasi memiliki modal yang cukup, maka koperasi akan mampu bertahan dan bersaing dengan koperasi lainnya atau usaha lainnya. Bagi akademik, kepada peneliti selanjutnya yang bermagsud melakukan penelitian di bidang koperasi, diharapkan untuk melakukan penelitian lebih lanjut dan mendalam terkait dengan analisis sumber dan penggunaan modal kerja menggunakan metode penelitian yang sama pada perusahaan lainnya atau menggunakan lebih dari satu koperasi maupun perusahaan. 


\section{DAFTAR PUSTAKA}

Amidipradja, Talman \& Wirasasmita, Rivani. 2005. Neraca Kopersi. Bandung: Pionir Jaya.

Jumingan. 2008. Analisi Laporan Keuangan (cetakan kedua). Jakarta: Bumi Aksara.

Kasmir. 2014. Analisis Laporan Keuangan (cetakan ke tujuh). Jakarta: PT. Raja Grafindo Persada.

Muljono, Djoko. 2012. Buku Pintar Strategi Bisni Koperasi Simpan Pinjam. Yogyakarta: CV. Andi Offset.

Munawir. 2004. Analisa Laporan Keuangan (edisi keempat, cetakan ketiga belas). Yogyakarta: Liberty.

Pachta, Andjar, Myra Rosana Bachtiar, dan Nadia Maulisa Benemay. 2005. Hukum Koperasi Indonesia. Yogyakarta: Liberty.

Riyanto, Bambang. 2001. Dasar-Dasar Pembelanjaan Perusahaan. Yogyakarta: BPFE.

Sartono, Agus. 2010. Manajemen Keuangan Teori dan Aplikasi (edisi keempat cetakan keempat). Yogyakarta: BPFE.

Sitio, Arifin, dan Halomoan. 2001. Koperasi Teori dan Praktek. Jakarta: Salemba Empat.

Subandi. 2013. Ekonomi Koperasi (Teori dan Praktik) Cetakan ke empat. Bandung: Alfabeta.

Sudarwanto, Adenk. 2013. Akuntansi Koperasi (edisi pertama, cetakan pertama). Yogyakarta: Graham IImu.

Undang-Undang Republik Indonesia No

25 Tahun 1992, tentang

Perkoperasian. 